Revista Eletrônica Geografar, Curitiba, v. 2, Resumos do VI Seminário Interno de Pós-Graduação em Geografia, p. 11-11. Junho/2007

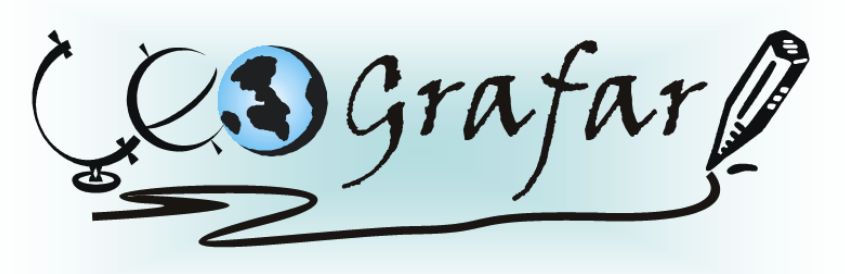

Revista Eletrônica do Programa de Pós-Graduação em Geografia - UFPR

\title{
O ENCONTRO DE TERRITORIALIDADES NO MUNICÍPIO DE ASSAI ANALISADO SOB O VIÉS DA TEORIA DA “DISSEMINAÇÃO”.
}

\author{
CARLA HOLANDA DA SILVA ${ }^{1}$
}

O encontro de populações culturais de diferentes origens é um elemento comum da sociedade brasileira, que apresenta inúmeras situações sociológicas de hibridismos que $\mathrm{H}$. BHABHA denomina como processos de "disseminação". O município de Assai, no Norte Velho do Paraná recebeu no início do século XX grande número de imigrantes japoneses que se instalaram no seu espaço rural. Pouco tempo depois chegaram à região populações nordestinas que se inseriam no mesmo espaço. A convivência e a cooperação destes dois grupos realizaram-se basicamente no campo da agricultura através de trocas, mas também com demarcações culturais formando um conjunto multicultural num único espaço. Surgiram territorialidades resultando num mosaico de territórios diferenciados. Neste sentido, a teoria de BHABHA é muito relevante, pois permite que se entenda a mútua inserção de etnicidades. A proposta da "Disseminação" coloca em debate a idéia da nação moderna "Brasil" sob o olhar de imigrantes discutindo a dinâmica nacional contraditória, que resulta de movimentos de dispersão e encontro nas margens da cultura homogênea definindo estrangeiros, guetos, inclusão e exclusão. Desenvolve-se, assim, ao mesmo tempo um conjunto de sujeitos que reúnem os seus passados e as memórias de culturas desenraizadas estabelecendo, um novo "local da cultura" e novas territorialidades. Portanto, a "DissemiNação", ou seja, a "DisSemiNação", é tanto um jogo de palavras que remete ao espalhar de identidades em uma nação de colonização/imigração como um fato de um migrante que se realiza e materializa num novo território: duas semi-nações, sempre mesclando perspectivas de deixar e receber, rejeitar e aceitar, incluir e excluir formam esta nação. Desenha-se territorialidades sob o viés da diferença cultural, tanto complexas como conflituosas e/ou harmoniosas, pois os dois grupos participam na criação de espaços sociais da época moderna do capitalismo tardio e do culturalismo pós-moderno que tanto reúne como divide sujeitos individuais e individualizados nos seus mundos.

Palavras-chave: "Disseminação", migrantes, territorialidades, diferença cultural.

${ }^{1}$ Mestranda em Geografia - UFPR - email: carla_holanda@hotmail.com Orientador: WOLF DIETRICH SAHR 